\title{
Pengaruh Pembelajaran Model Creative Problem Solving (CPS) terhadap Kemampuan Berpikir Kritis ditinjau dari Kemampuan Awal Matematis Siswa Sekolah Menengah Atas
}

\author{
Erdawati Nurdin $^{1 *}$, Desti Daragita Nayan ${ }^{2}$, Risnawati ${ }^{3}$ \\ 1,2,3 Program studi pendidikan matematika, Universitas Islam Negeri Sultan Syarif Kasim Riau, 28293, Indonesia \\ Pengiriman: 1/Maret/2020; Diterima: 24/Maret/2020; Publikasi: 31/Maret/2020 \\ DOI: https://doi.org/10.31629/jg.v5i1.2151
}

\begin{abstract}
Abstrak
Penelitian ini bertujuan untuk mengetahui ada atau tidaknya perbedaan kemampuan berpikir kritis siswa yang mengikuti pembelajaran model Creative Problem Solving (CPS) jika ditinjau dari kemampuan awal matematis siswa. Desain yang digunakan pada penelitian kuasi eksperimen adalah the non-equivalent posttest only control group design. Populasi pada penelitian ini adalah siswa SMA N Plus Pekanbaru. Sampel pada penelitian ini dipilih secara purposif. Sampel dalam penelitian ini adalah kelas XI MS 1 sebagai kelompok eksperimen dan kelas XI MS 2 sebagai kelompok kontrol. Berdasarkan analisis data menggunakan uji anova dua arah diperoleh kesimpulan bahwa: (1) Terdapat perbedaan kemampuan berpikir kritis siswa yang belajar menggunakan pembelajaran model Creative Problem Solving (CPS) dengan siswa yang belajar menggunakan pembelajaran konvensional, (2) Terdapat perbedaan kemampuan berpikir kritis siswa yang mengikuti pembelajaran model Creative Problem Solving (CPS) dengan siswa yang mengikuti pembelajaran konvensional, jika ditinjau dari kemampuan awal matematis siswa, (3) Tidak terdapat pengaruh interaksi antara model pembelajaran yang ditinjau dari kemampuan awal matematis terhadap kemampuan berpikir kritis siswa. Dalam hal ini model Creative Problem Solving (CPS) baik digunakan pada siswa yang memiliki kemampuan awal matematis tinggi dan sedang.
\end{abstract}

Kata kunci: kemampuan awal matematis; kemampuan berpikir kritis; model creative problem solving

\begin{abstract}
This study aims to determine the effect of Creative Problem Solving (CPS) learning toward mathematical critical thingking based on prior knowledge. This study is quasy experimental research. The non-equivalent posttest only control group design was used. The population of this study is students of SMA N Plus Pekanbaru. The sample was chosen purposively. Students in class XI MS 1 as experimental grup and XI MS 2 as control grup. Analisis of varians test was used. The conclutions are: (1) there is a difference in mathematical critical thinking of students who learn to use the CPS learning with students who use conventional learning, (2) there is a difference in mathematical critical thinking of students who learn to use the CPS learning with students who use conventional learning based on entry knowledge, and (3) there is no effect of interaction between the learning models and entry knowledge toward students mathematical critical thinking ability. The CPS learning model is good to use for students who have good mathematical prior knowledge.
\end{abstract}

Keywords: mathematical entry knowledge; mathematics critical thinking; creative problem solving; learning

*Penulis Korespondensi 


\section{JURNAL GANTANG. Maret 2020; V(1): 39 - 49 \\ p-ISSN. 2503-0671 \\ e-ISSN. 2548-5547}

\section{Pendahuluan}

Matematika merupakan mata pelajaran yang dipelajari di setiap jenjang pendidikan dari tingkat sekolah dasar sampai sekolah menengah atas bahkan perguruan tinggi. Berdasarkan Permendikbud no. 20 tahun 2016 mensahkan Standar Kompetensi Lulusan (SKL) mata pelajaran matematika SMA/MA/SMALB/Paket $C$ yang salah satunya ialah siswa harus memiliki keterampilan berpikir kritis, produktif, kreatif, mandiri, kolaboratif dan komunikatif (Permendikbud, 2016). Dari keenam keterampilan tersebut kemampuan berpikir kritis merupakan kemampuan yang harus dimiliki siswa. Oleh karena itu, berpikir kritis merupakan bagian dari SKL mata pelajaran matematika.

Selain itu, pembelajaran matematika pada abad 21 memiliki tujuan dengan karakteristik 4C atau yang biasa disebut 4C's, yaitu: Critical Thinking (berpikir kritis), Communication (komunikasi), Collaboration (kolaburasi), dan Creativity (kreatif) (Sunardi et al., 2017). Hal ini ditegaskan oleh (Hendriana et al., 2017) menyatakan bahwa salah satu kemampuan dasar matematika yang essesial dan perlu dimiliki oleh siswa yang belajar matematika adalah kemampuan berpikir matematis. Oleh karena itu, kemampuan berpikir kritis ini menjadi tujuan yang sangat penting dalam pembelajaran matematika. Begitu pula yang diungkapkan oleh Zoller, Ben-Chaim \& Ron bahwa mengembangkan kemampuan berpikir kritis siswa dalam pembelajaran menjadi tujuan utama dalam dunia pendidikan (Fauzi \& Abidin, 2019).

Menurut Reber, dalam hal berpikir kritis, siswa dituntut menggunakan strategi kognitif tertentu untuk menguji keandalan gagasan pemecahan masalah dan mengatasi kesalahan atau kekurangan (Muhibbin, 2008). Sebagaimana disampaikan oleh Johnson menyatakan bahwa berpikir kritis merupakan proses yang fokus dan jelas digunakan dalam kegiatan mental seperti menyelesaikan masalah, membuat keputusan, membujuk, menganalisis asumsi, dan melakukan penelitian ilmiah (Zetriuslita et al., 2016).
Menurut Klurick dan Rudnick, proses ini melibatkan aktivitas menguji, menghubungkan, dan mengevaluasi semua aspek sebuah situasi atau masalah, termasuk juga mengumpulkan, mengorganisasikan, mengingat dan menganalisis informasi (Ariyanti et al., 2019). Selain itu, Wijaya menjelaskan bahwa berpikir kritis merupakan sebuah proses penggunaan kemampuan berpikir secara terarah dan jelas untuk membantu sesorang menyusun, mengevaluasi dan mengaplikasikan keputusan tentang apa yang dipercaya dan dikerjakan(Atika \& MZ, 2016). Melalui proses berpikir kritis siswa dapat mengembangkan pola pikir yang logis (Imamuddin et al., 2019).

Berbagai pernyataan tersebut menunjukkan pentingnya kemampuan berpikir kritis, terutama dalam pembelajaran. Siswa yang mampu berpikir secara kritis dapat menganalisis informasi untuk mengatasi masalah, menganalisis asumsi untuk membuat keputusan tepat dan akhirnya mampu mengembangkan pola pikir yang logis dalam menyelesaikan suatu persoalan. Namun fakta di lapangan menunjukkan bahwa kemampuan berpikir kritis siswa belum sesuai dengan diharapkan. Hasil prariset peneliti di SMA Negeri Plus Provinsi Riau kelas XI MS 1, menunjukkan bahwa siswa tidak mampu menyelesaikan soal yang menguji kemampuan berpikir kritis. Skor rata-rata ketercapaian kemampuan berpikir kritis siswa hanya mencapai 8,6 dari skor maksimal 24.

Tentunya, hal ini harus menjadi perhatian bagi para pendidik, salah satunya guru. Astuti et al. (2017) menyatakan bahwa pertanyaan lisan dari guru tidak cukup efektif untuk memfasilitasi kemampuan berpikir kritis siswa. Guru perlu mencari alternatif yang mampu mengembangkan kemampuan berpikir kritis siswa. Solusi yang dapat dilakukan adalah dengan memilih model pembelajaran yang sesuai. Salah satu model pembelajaran yang dianggap mampu mengatasi masalah kemampuan berpikir kritis adalah model pembelajaran Creative Problem Solving (CPS). Istarani \& Ridwan (2014) menyatakan bahwa 
model pembelajaran CPS memiliki beberapa kelebihan salah satunya yaitu pembelajaran CPS melatih dan menumbuhkan kreativitas, kognitif tinggi, kritis, komunikasi-interaksi, keterbukaan, dan sosialisasi. Model pembelajaran CPS bertugas untuk mengarahkan upaya pemecahan masalah secara kritis, sehingga siswa bisa mengambil keputusan dalam menyelesaikan masalah secara logis.

Model pembelajaran CPS merupakan pembelajaran yang berpusat pada keterampilan dan kreativitas siswa dalam menyelesaikan masalah matematik dengan cara mengklarifikasi masalah terlebih dahulu, mengungkapkan gagasan untuk mencari strategi penyelesaian masalah, memeriksa kebenaran jawaban, dan menerapkan langkah-langkah penyelesaian masalah yang sementara dihadapi dan memikirkan langkah-langkah pada masalah yang lebih luas (Nurjannah \& Irma, 2019). Dalam model CPS ini, siswa dituntut untuk berpikir kritis melalui bagaimana siswa mengidentifikasi fakta dan memilih atau memutuskan informasiinformasi mana sajakah yang relevan dengan masalah yang diberikan. Tidak hanya itu, siswa juga dituntut untuk mampu mengevaluasi dari setiap ide atau gagasan yang ditemukannya (Retnawati et al., 2018). Sehingga dengan model pembelajaran CPS ini, siswa dituntut untuk menumbuhkan dan melatih kemampuan berpikir kritis siswa dalam menyelesaikan permasalahan.

Selain itu, pembelajaran CPS merupakan suatu model pembelajaran yang menekankan pemecahan masalah dan berpikir kreatif, melalui proses berpikir divergen dan konvergen. Proses berpikir divergen melahirkan suatu kreativitas berpikir siswa dalam memahami dan menyelesaikan suatu masalah, sedangkan berpikir konvergen melahirkan suatu keputusan solusi yang tepat untuk masalah yang dihadapi (Isrok'atun \& Rosmala, 2018).

Dari pemaparan tersebut dapat dilihat pada CPS merupakan model problem solving yang memiliki kekhasan creative pada guru maupun siswa. Guru harus kreatif dalam memberikan masalah yang dimana masalah tersebut dapat diselesaikan dengan berbagai cara dan pemecahan yang beragam sehingga menuntut kreativitas siswa dalam penyelesaiannya.

Faktor lain yang juga menentukan keberhasilan siswa dalam mempelajari matematika ialah kemampuan awal matematis. Praptiwi \& Handhika (2012) menegaskan bahwa kemampuan awal akan mempengaruhi keberhasilan siswa dalam pembelajaran. Kemampuan awal siswa adalah kemampuan yang telah dimiliki oleh siswa sebelum mengikuti pembelajaran yang diberikan. Kemampuan awal (entry behavior) ini menggambarkan kesiapan siswa dalam menerima pelajaran yang akan disampaikan oleh guru (Lestari, 2017). Dengan demikian, kemampuan awal matematis ini dapat dikatakan sebagai pengetahuan dan keterampilan yang telah dimiliki siswa yang berkaitan dengan materi yang akan dipelajari. Kemampuan ini dibutuhkan siswa dalam menyelesaikan persoalan matematis yang dihadapinya (Mardaleni et al., 2018).

Berbagai penelitian terkait pengaruh pembelajaran CPS terhadap kemampuan berpikir kritis siswa sudah bnyak dilakukan, diantaranya penelitian yang dilakukan oleh (Husnawati et al., 2015 ; Novitasari, 2015). Namun, penelitianpenelitian tersebut belum melihat KAM sebagai variabel moderator, Oleh karena itu, maka peneliti termotivasi untuk melakukan penelitian yang lebih mendalam mengenai kemampuan berpikir kritis matematis yang mempertimbangkan KAM sebagai salah satu variabel. Adapun tujuan penelitian ini adalah untuk melihat pengaruh pembelajaran model Creative Problem Solving (CPS) terhadap kemampuan berpikir kritis ditinjau dari kemampuan awal matematis Siswa Sekolah Menengah Atas. Hasil penelitian ini diharapkan dapat menjadi salah satu pertimbangan bagi guru dalam memilih model/pendekatan pembelajaran terkait kemampuan berpikir kritis matematis siswa. 


\section{JURNAL GANTANG. Maret 2020; V(1): 39 - 49 \\ p-ISSN. 2503-0671 \\ e-ISSN. 2548-5547}

\section{Metode Penelitian}

Penelitian ini merupakan penelitian kuantitatif. Jenis penelitian yang sesuai adalah penelitian eksperimen. Namun dikarenakan banyak faktor yang tidak dapat dikontrol secara penuh, misalnya kesehatan siswa, motivasi belajar dan lain-lain, maka jenis penelitian yang dilakukan adalah kuasi eksperimen. Desain yang digunakan peneliti adalah the nonequivalent pretest posttest only control group design. Penelitian ini melibatkan dua kelompok sampel yaitu kelompok eksperimen yang diterapkan pembelajaran model Creative Problem Solving (CPS) dan kelompok kontrol yang diterapkan pembelajaran konvensional.

Populasi pada penelitian ini adalah seluruh siswa kelas XI SMA Negeri Plus Provinsi Riau tahub ajaran 2019/2020. Sampel dipilih secara purposif, dengan menggunakan pertimbangan dari guru mata pelajaran terhadap pengamabilan sampel dari populasi yang akan diteliti. Untuk memperkuat penentuan sampel peneliti menganalisis hasil tes kemampuan awal matematis siswa dengan melakukan uji perbandingan untuk menunjukkan bahwa kedua kelas tersebut memiliki kemampuan awal yang sama sebelum pembelajaran CPS diterapkan.

Instrumen pengumpulan data dalam penelitian ini adalah soal tes kemampuan awal matematis, soal tes kemampuan berpikir kritis dan lembar observasi. Data kemampuan awal kemudian dibagi menjadi tiga kategori. Kemudian, karena pada penelitian ini melibatkan dua faktor dan untuk melihat pengaruh interaksi antara dua faktor yang terdiri dari dua atau lebih kategori kemampuan awal terhadap variabel kemampuan berpikir kritis matematis siswa, maka teknik analisis data yang digunakan adalah anova dua jalur. Adapun hipotesis dalam penelitian ini sebagai berikut:

\section{Hipotesis 1}

Terdapat perbedaan kemampuan berpikir kritis siswa yang belajar menggunakan pembelajaran model Creative Problem Solving (CPS) dengan siswa yang belajar menggunakan pembelajaran konvensional.

\section{Hipotesis 2}

Terdapat perbedaan kemampuan berpikir kritis siswa yang mengikuti pembelajaran model Creative Problem Solving (CPS) dengan siswa yang mengikuti pembelajaran konvensional, jika ditinjau dari kemampuan awal matematis siswa.

\section{Hipotesis 3}

Terdapat pengaruh interaksi antara model pembelajaran yang ditinjau dari kemampuan awal matematis terhadap kemampuan berpikir kritis siswa.

\section{Hasil dan Pembahasan Hasil}

Sebelum membahas uji hipotesis penelitian, berikut dipaparkan hasil observasi aktivitas guru dan siswa selama penelitian. Sejak pertemuan awal, pembelajaran CPS di kelompok eksperimen berjalan dengan baik, dengan ketercapaian 90,91\%. Langkah-langkah yang belum terlaksana dengan baik yaitu klarifikasi masalah, pengungkapkan pendapat, dan implementasi. Hal ini disebabkan, pada pertemuan ini masih banyak kekurangan dalam melaksanakan model pembelajaran dengan baik dan merasa gugup dalam menghadapi siswa, sehingga ada beberapa langkah yang belum maksimal dilakukan, maka dibutuhkannya pembiasaan. Penerapan pembelajaran CPS terlaksana secara tuntas pada pertemuan keenam, maka pertemuan berikutnya diadakan tes untuk mengukur kemampuan berpikir kritis siswa.

Aktivitas siswa juga tidak luput dari perhatian peneliti. Selama proses pembelajaran berlangsung, kegiatan siswa yang diharapkan dalam pembelajaran dengan pembelajaran model CPS dinilai melalui lembar observasi. Dari lembar aktivitas siswa diketahui bahwa pada pertemuan awal ini masih ada langkah-langkah yang belum terlaksana dengan baik. Penerapan model CPS baru mencapai $88,64 \%$. Pada awal pertemuan siswa masih sulit mengklarifikasi masalah, beberapa siswa masih malu mengungkapkan pendapat, binggung dalam melakukan evaluasi dan memilih hingga mengimplementasikan. Hal ini disebabkan siswa 
yang masih kebingungan belajar menggunakan pembelajaran model CPS. Pada pertemuan selanjutnya terjadi peningkatan disebabkan siswa sudah mulai terbiasa belajar menggunakan pembelajaran model CPS. Sehingga pada langkah pengungkapan pendapat dan implementasi sudah terlaksana dengan baik. Pada pertemuan keenam pelaksanaan pembelajaran CPS sudah mencapai $100 \%$ yang menunjukkan bahwa pelaksanaan pembelajaran matematika dengan menggunakan pembelajaran model CPS sudah terlaksana sepenuhnya.

Selanjutnya, dilakukan analisis terhadap kemampuan awal matematis (KAM) siswa. Adapun deskripsi kemampuan awal matematis siswa di kedua kelompok dapat dilihat pada berikut:

Tabel 1.

Deskripsi KAM siswa

\begin{tabular}{lccccc}
\hline Kelompok & $\bar{X}$ & $S D$ & $X_{\max }$ & $X_{\min }$ & $\begin{array}{c}\text { Skor } \\
\text { Ideal }\end{array}$ \\
\hline Eksperimen & 9,13 & 4,21 & 19 & 3 & 20 \\
\hline Kontrol & 8,53 & 4,5 & 20 & 2 & 20 \\
\hline
\end{tabular}

Terlihat pada tabel 1, bahwa rata-rata kemampuan awal matematis kedua kelompok tidak berbeda jauh, yaitu hanya berselisih 0,6. Untuk membuktikan bahwa perbedaan ini tidak signifikan maka dilakukan uji perbedaan terhadap rata-rata kemampuan awal matematis kedua kelompok tersebut. Sebelum melakukan uji perbedaan terlebih dahulu dilakukan uji prasyarat analisis seperti uji normalitas dan uji homogenitas. Perhitungan uji normalitas menggunakan uji Chi kuadrat dapat dilihat pada tabel berikut:

Tabel 2.

Uji normalitas KAM

\begin{tabular}{lcccc}
\hline Kelompok & $X^{2}{ }_{\text {hitung }}$ & $X^{2}{ }_{\text {hitung }}$ & Kriteria \\
\cline { 1 - 2 } Eksperimen & 4,07 & \multirow{2}{*}{11,07} & Normal \\
\cline { 1 - 2 } Kontrol & 2,67 & & Normal \\
\hline
\end{tabular}

Dari perhitungan yang telah dilakukan diketahui bahwa $X^{2}{ }_{\text {hitung }}$ dari kedua kelompok kurang dari $X^{2}{ }_{\text {tabel }}$ sehingga dapat disimpulkan bahwa data kedua kelas berdistribusi normal.
Kemudian, hasil uji homogenitas rata-rata kemampuan awal matematis dapat dilihat pada tabel 3 .

Tabel 3.

Uji homogenitas KAM

\begin{tabular}{ccccc}
\hline \multirow{2}{*}{$\begin{array}{c}\text { Nilai } \\
\text { Varians }\end{array}$} & \multicolumn{2}{c}{ Kelompok } & $F_{\text {hitung }}$ & $F_{\text {tabel }}$ \\
\cline { 2 - 3 } & Eks & Kontrol & & \\
\hline$S$ & 17,71 & 20,26 & 1,14 & 1,85 \\
\hline$N$ & 30 & 30 & & \\
\hline \multicolumn{2}{r}{ Pada } & taraf & signifikan & $\alpha=0,05$,
\end{tabular}
diperoleh nilai $F_{\text {tabel }}=1,85$. Karena $F_{\text {hitung }}=$ 1,14 dan $F_{\text {tabel }}=1,85$, maka $F_{\text {hitung }}<F_{\text {tabel }}$ atau $1,14<1,85$ sehingga dapat disimpulkan bawa rata-rata KAM siswa bervariansi homogen. Karena rata-rata KAm siswa berdistribusi normal dan variansinya homengen, maka uji perbedaan rata-rata dapat dilakukan menggunakan uji t. Hasil uji-t rata-rata KAM dapat dilihat pada tabel 4.

Tabel 4.

Uji-t KAM

\begin{tabular}{ccc}
\hline$t_{\text {hitung }}$ & $\begin{array}{c}t_{\text {tabel }} \\
(\alpha=5 \%)\end{array}$ & Keterangan \\
\hline 0,52 & 2,00 & $\mathrm{H}_{\mathrm{o}}$ diterima \\
\hline
\end{tabular}

Dari tabel di atas diketahui bahwa $t_{\text {hitung kurang dari } t_{\text {tabel }} \text { sehingga dapat }}$ disimpulkan bahwa kedua kelas tidak memiliki perbedaan kemampuan awal matematis. Selanjutnya siswa di kedua kelompok dibagi menjadi 3 kategori berdasarkan nilai KAM, seperti pada tabel berikut:

Tabel 5.

Kriteria pengelompokan KAM

\begin{tabular}{cc}
\hline Kriteria KAM & Kategori \\
\hline$x \geq(13,16)$ & Tinggi \\
\hline$(4,50)<x<(13,16)$ & Sedang \\
\hline$x \leq(4,50)$ & Rendah \\
\hline
\end{tabular}

Terdapat 5 siswa kategori tinggi di kelompok eksperimen dan 5 orang di kelompok kontrol. Pada kategori rendah, 4 orang di kelompok eksperimen dan 7 orang di kelompok kontrol. Sissanya, 19 orang di masing-masing kelompok berada pada kategori sedang.

Selanjutnya, untuk pengujian hipotesis 
JURNAL GANTANG. Maret 2020; V(1): 39 - 49

p-ISSN. 2503-0671

e-ISSN. 2548-5547

digunakan data rata-rata kemampuan berpikir kritis siswa. Deskripsi kemampuan berpikir matematis siswa dapat dilihat pada tabel berikut.

Tabel 6.

Deskripsi kemampuan berpikir kritis siswa

\begin{tabular}{lccccc}
\hline Kelompok & $\bar{X}$ & $S D$ & $X_{\max }$ & $X_{\min }$ & $\begin{array}{c}\text { Skor } \\
\text { Ideal }\end{array}$ \\
\hline Eksperimen & 14,17 & 3,48 & 20 & 8 & 20 \\
\hline Kontrol & 11,4 & 414 & 19 & 5 & 20 \\
\hline
\end{tabular}

Pada tabel 6, terlihat bahwa terdapat perbedaan rata-rata kemampuan berpikir kritis matematis sebesar 2,77 lebih tinggi kelompok eksperimen daripada kelompok kontrol. Untuk membuktikan bahwa perbedaan ini signifikan maka dilakukan uji statistik. Untuk menentukan uji statistik yang akan digunakan, maka dilakukan uji normalitas dan uji homogenitas. Hasil uji normalitas rata-rata kemampuan berpikir kritis siswa dapat dilihat pada tabel berikut.

Tabel 7.

Uji normalitas kemampuan berpikir kritis siswa

\begin{tabular}{lccl}
\hline Kelompok & $X^{2}{ }_{\text {hitung }}$ & $X^{2}{ }_{\text {tabel }}$ & Kriteria \\
\hline Eksperimen & 3,92 & 11,07 & Normal \\
\hline Kontrol & 3,71 & 11,07 & Normal \\
\hline
\end{tabular}

Dari perhitungan yang telah dilakukan diketahui bahwa $X^{2}{ }_{\text {hitung dari kelompok }}$ eksperimen dan kontrol kurang dari $X^{2}$ tabel sehingga dapat disimpulkan bahwa rata-rata kemampuan berpikir kritis kedua kelompok berdistribusi normal. Kemudian, hasil uji homogenitas kemampuan berpikir kritis siswa dapat dilihat dari tabel 8 .

Tabel 8.

Uji homogenitas kemampuan berpikir kritis siswa

\begin{tabular}{|c|c|c|c|c|}
\hline Nilai & \multicolumn{2}{|c|}{ Kelompok } & \multirow[t]{2}{*}{$\overline{F_{\text {hitung }}}$} & \multirow[t]{2}{*}{$F_{\text {tabel }}$} \\
\hline Varians & Eks & Kontrol & & \\
\hline$S$ & 12,14 & 1,14 & 1,14 & 1,85 \\
\hline$N$ & 30 & 30 & & \\
\hline
\end{tabular}

Pada taraf signifikan $\alpha=0,05$, diperoleh nilai $F_{\text {tabel }}=1,85$. Karena $F_{\text {hitung }}=1,41$ dan $F_{\text {tabel }}=1,85$ maka $F_{\text {hitung }}<F_{\text {tabel }}$ atau $1,41<1,85$ sehingga dapat disimpulkan bahwa kemampuan berpikir kritis siswa bervariansi homogen. Selanjutnya, dilakukan uji hipotesis menggunakan uji anova dua arah. Uji yang dilakukan dengan kriteria jika nilai signifikan yang diperoleh lebih kecil dari 0,05 maka $H_{0}$ diterima, jika nilai signifikan yang diperoleh lebih besar dari 0,05 maka $H_{a}$ diterima. Berikut hasil uji anova dua arah terangkum pada tabel 9 .

Tabel 9.

Hasil uji anova dua arah

\begin{tabular}{lccccc}
\hline $\begin{array}{l}\text { Sumber } \\
\text { Variansi }\end{array}$ & $\mathrm{dk}$ & $J K$ & $R K$ & $F h$ & $\boldsymbol{F t}$ \\
\hline $\begin{array}{l}\text { Antar } \\
\text { Baris }\end{array}$ & 1 & 114,82 & 114,82 & 8,61 & 4,02 \\
\hline $\begin{array}{l}\text { Antar } \\
\text { Kolom }\end{array}$ & 2 & 138,21 & 69,1 & 5,18 & 3,17 \\
\hline Baris* & 2 & $-8,91$ & $-4,46$ & $-0,33$ & 3,17 \\
Kolom & & & & & \\
\hline Dalam & 4 & 720,07 & 13,33 & & \\
\hline Total & 9 & 964,18 & & & \\
\hline
\end{tabular}

Tabel 10 menunjukkan bahwa: (a) $F(A)_{\text {hitung }}>F(A)_{\text {tabel }}$ maka $H_{a}$ diterima sehingga disimpulkan bahwa pada taraf signifikan 5\% terdapat perbedaan kemampuan berpikir kritis siswa yang belajar menggunakan pembelajaran model Creative Problem Solving (CPS) dengan siswa yang belajar menggunakan pembelajaran konvensional. (b) $F(B)_{\text {hitung }}>$ $F(B)_{\text {tabel }}$ maka $H_{a}$ diterima sehingga disimpulkan bahwa pada taraf signifikan 5\% terdapat perbedaan kemampuan berpikir kritis siswa yang mengikuti pembelajaran model Creative Problem Solving (CPS) dengan siswa yang mengikuti pembelajaran konvensional, jika ditinjau dari kemampuan awal matematis siswa.

Terakhir, (c) $\quad F(A x B)_{\text {hitung }}<$ $F(A \times B)_{\text {tabel }}$ maka $H_{o}$ diterima sehingga disimpulkan bahwa pada taraf signifikan 5\% tidak terdapat pengaruh interaksi antara model pembelajaran yang ditinjau dari kemampuan awal matematis terhadap kemampuan berpikir kritis siswa.

\section{Pembahasan}

Berdasarkan analisis data diketahui bahwa terdapat perbedaan yang signifikan kemampuan berpikir matematis siswa yang menerapkan model CPS dengan siswa yang 
memperoleh pembelajaran konvensional. Pada pembelajaran model CPS siswa dituntut untuk mengidentifikasi fakta dan memilih atau memutuskan informasi-informasi mana sajakah yang relevan dengan masalah yang diberikan, memberikan alasan yang logis dan kuat serta menyimpulkan secara tepat. Di awal pembelajaran siswa dihadapkan pada masalah yang memiliki beragam cara dan penyelesaian. Menurut Noller persoalan yang memiliki banyak alternatif pemecahan masalah, terbuka dalam perbaikan, menumbuhkan kepercayaan diri, keberanian menyampaikan pendapat, berpikir divergen, dan fleksibel dalam upaya pemecahan masalah (Suryosubroto, 2009). Dengan bantuan guru, siswa diarahkan untuk mengidentifikasi fakta-fakta dan informasi yang terdapat pada masalah yang diberikan. Sehingga mereka mampu mengevaluasi dan memilih informasi yang dibutuhkan untuk menyelesaikan persoalan yang ada. Melalui sharing ide dan gagasan antar siswa, siswa diajak untuk menemukan berbagai cara dan jawaban permasalahan tersebut. Siswa juga dibimbing untuk mengungkapkan alasan yang logis dari ide-ide yang mereka sampaikan. Dengan demikian siswa mampu mengembangkan kecermatan dalam merumuskan dan memutuskan keyakinan sendiri serta mampu mengambil keputusan dengan tepat dalam menyelesaikan persoalan yang ada. Dari tahapan tersebut, nampak bahwa siswa aktivitas siswa selama pembelajaran CPS dapat mendorong perkembangan kemampuan berpikir kritis matematis siswa.

Penelitian yang dilakukan oleh Wahyuni et al. (2018) menyimpulkan bahwa peningkatan kemampuan berpikir kritis matematis siswa yang menerapkan pembelajaran model CPS lebih baik dibanding siswa yang memperoleh pembelajaran langsung. Senada dengan kesimpulan tersebut, penelitian Hanafi (2019) mengungkapkan pengaruh positif pembelajaran CPS terhadap kemampuan berpikir kritis dan disposisi matematis siswa. Adapun indikator kemampuan berpikir kritis pada penelitian ini adalah indikator yang diungkapkan oleh Ennis (1996), yaitu: (a)
Focus (fokus), ialah memperhatikan atau menggambarkan situasi, isu-isu, pertanyaan, masalah, atau hal-hal utama atau penting; (b) Reasons (bernalar), ialah upaya mendapatkan ide-ide yang cukup baik berdasarkan pertimbangan masuk akal; (c) Situation (situasi), ialah suatu keadaan yang melibatkan orangorang dan tujuan-tujuannya, sejarah, pengetahuan, emosi, praduga-praduga, keanggotaan, dan keinginan/kepentingankepentingan; (d) Clarity (kejelasan) ialah suatu keadaan yang dapat dimengerti dengan mudah dan tidak terdapat kekacauan/kerumitan dan (e) Overview (peninjauan) adalah memeriksa secara menyeluruh apa yang sudah ditemukan, diputuskan, dipertimbangkan, dipelajari, dan disimpulkan. Deskripsi rata-rata kemampuan berpikir kritis siswa berdasarkan indikator dapat dilihat pada diagram berikut:

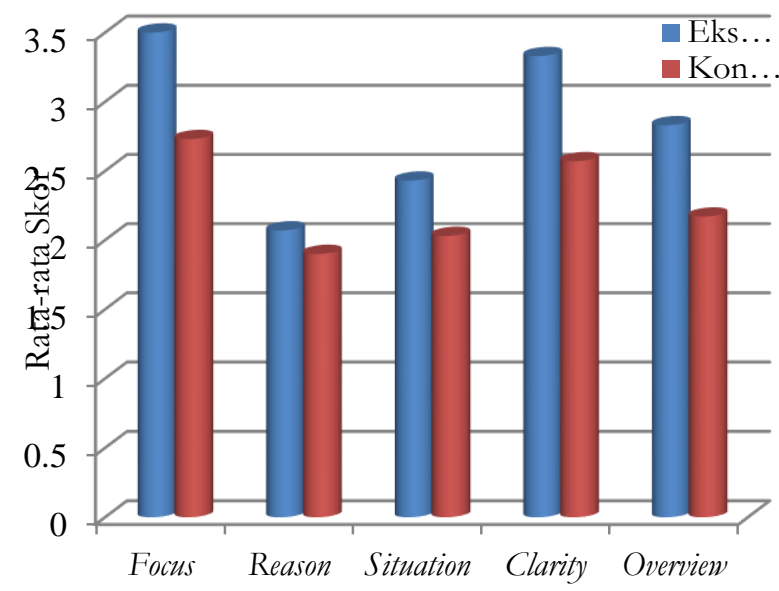

Gambar 1. Diagram Kemampuan Kemampuan Berpikir Kritis Perindikator

Pada diagram di atas terlihat bahwa terdapat perbedaan besar pada indikator focus, clarity dan overview. Artinya, siswa di kelompok eksperimen lebih mampu menggambarkan masalah, memberikan contoh yang jelas dan relevan serta memeriksa kebenaran jawaban secara tepat. Namun, untuk indikator reason dan situation, kedua kelompok hamper memiliki kemampuan yang sama. Jadi, baik kelompok eksperimen dan kelompok kontrol masih kurang mampu dalam hal memberikan alasan yang logis dan menerapkan konsep pengetahuan 
JURNAL GANTANG. Maret 2020; V(1): 39 - 49

p-ISSN. 2503-0671

e-ISSN. 2548-5547

sebelumnya.

Pada hipotesis kedua, diperoleh keisimpulan bahwa terdapat perbedaan kemampuan berpikir kritis siswa yang mengikuti pembelajaran model Creative Problem Solving (CPS) dengan siswa yang memperoleh pembelajaran konvensional, jika ditinjau dari KAM. Berikut disajikan deskriptif kemampuan berpikir kritis berdasarkan KAM.

Tabel 11.

Deskripsi kemampuan berpikir kritis berdasarkan KAM

\begin{tabular}{ccccc}
\hline Kategori & \multicolumn{2}{c}{$\bar{X}$} & \multicolumn{2}{c}{$S D$} \\
\cline { 2 - 5 } KAM & Eks & Kontrol & Eks & Kontrol \\
\hline Tinggi & 15,67 & 12,25 & 4,13 & 4,11 \\
\hline Sedang & 14,74 & 11,89 & 2,73 & 4,08 \\
\hline Rendah & 10,2 & 9,57 & 2,95 & 4,39 \\
\hline
\end{tabular}

Tabel di atas menunjukkan bahwa KAM

turut mempengaruhi kemampuan berpikir matematis siswa. Zulkarnain (2019) mengungkapkan bahwa KAM berpengaruh positif terhadap hasil belajar siswa. Hal ini sejalan dengan penelitian yang dilakukan oleh Mawarni et al., (2019). Penelitian tersebut menyimpulkan bahwa KAM memiliki peranan penting dalam mengembangkan kemampuan berpikir kritis siswa. Siswa dengan KAM tinggi memiliki kemampuan berpikir kritis yang lebih baik. Jika ditinjau dari KAM, maka pembelajaran model CPS lebih baik digunakan untuk siswa yang memiliki KAM minimal sedang. Siregar et al., (2018) mengungkapkan bahwa model pembelajaran tidak memberikan pengaruh positif terhadap kemampuan berpikir kritis bagi siswa yang memiliki KAM rendah. Hal ini dikarenakan untuk mampu berpikir secara kritis, siswa memerlukan pengetahuan prasyarat yang baik, agar mereka bias menganalisis informasiinformasi yang baru mereka peroleh menggunakan pengetahuan yang telah mereka miliki sebelumnya. Misrayanti \& Amir (2019) menyatakan bahwa KAM merupakan kemampuan seseorang yang diperoleh dari pelatihan selama hidupnya, dan apa yang dibawa untuk menghadapi suatu pengalaman barunya. Pemanfaatan kemampuan awal matematis pada kegiatan pembelajaran secara optimal dapat membantu mempermudah dan mempercepat proses penumbuhan pengetahuan baru. Dimana dari kemampuan awal matematis ini akan membangun pengetahuan-pengetahuan baru guna untuk meningkatkan kemampuan berpikir kritis siswa.

Terakhir, untuk hipotesis ketiga, diperoleh kesimpulan bahwa tidak terdapat pengaruh interaksi antara model pembelajaran yang ditinjau dari kemampuan awal matematis terhadap kemampuan berpikir kritis siswa. Begitu pula dengan penelitian yang dilakukan oleh Jumaisyaroh et al. (2015). Penelitian tersebut menyimpulkan bahwa tidak terdapat interaksi antara pembelajaran dengan KAM (tinggi, sedang, dan rendah) terhadap peningkatan kemampuan berpikir kritis siswa. Hal ini menunjukkan bahwa pengaruh model pembelajaran yang digunakan lebih besar terhadap kemampuan berpikir kritis matematis dibandingkan KAM siswa. Hasil penelitian Nindiasari et al. (2014) menyimpulkan bahwa pemilihan model/pendekatan pembelajaran memberi pengaruh lebih besar terhadap hasil belajar siswa dibanding KAM dan level sekolah. Dengan demikian, pemilihan model pembelajaran yang digunakan guru sangat menentukan keberhasilan siswa dibandingkan variabel lain. Namun, dalam memilih model pembelajaran yang akan digunakan, guru harus tetap mempertimbangkan kesesuaian model tersebut dengan materi dan kemampuan siswa.

Dengan demikian, dapat dikatakan bahwa model pembelajaran terhadap kemampuan berpikir kritis siswa tidak bergantung pada KAM dan KAM terhadap kemampuan berpikir kritis siswa tidak bergantung pada model pembelajaran yang digunakan. Jadi, model pembelajaran dan KAM mempunyai posisi sendiri terhadap kemampuan berpikir kritis siswa. Hal ini sejalan dengan yang dikemukakan oleh Panitz bahwa tidak terjadinya interaksi antara model pembelajaran dan variabel moderator terhadap variabel terikat karena adanya pengaruh utama yang kuat dari variabel 
bebas dan variabel moderator terhadap variabel terikat, sehingga melemahkan interaksi yang ada (Suprapto, 2017).

\section{Kesimpulan}

Rendahnya kemampuan berpikir kritis siswa di Indonesia tentunya menjadi momok bagi para pendidik. Salah satu solusi yang dapat diupayakan adalah dengan menerapkan model pembelajaran yang mampu mengembangkan kemampuan berpikir kritis siswa. Salah satu alternatifnya adalah, model pembelajaran Creative Problem Solving (CPS). Penelitian kuasi eksperimen ini membuktikan pengaruh positif model pembelajaran CPS terhadap kemampuan berpikir matematis siswa. Berdasarkan uji anova dua arah menunjukkan bahwa kemampuan awal matematis (KAM) turut andil dalam perkembangan kemampuan berpikir kritis siswa, walaupun tidak ada pengaruh interaksi antara model pembelajaran yang digunakan dengan KAM. Model CPS dapat menjadi alternatif pembelajaran yang ditujukan untuk memfasilitasi kemampuan berpikir kritis siswa. Dengan catatan, guru kreatif dalam mengajukan masalah, menggiring siswa untuk menemukan berbagai cara dan solusi dalam menyelesaika persoalan yang ada. Guru juga harus memperhatikan KAM siswa, memastikan siswa telah memiliki pengetahuan prasyarat yang dibutuhkan dan siap untuk menerima pengetahuan baru.

\section{Referensi}

Ariyanti, D., Isnaniah, I., \& Jasmienti, J. (2019). Pengaruh Penerapan model pembelajaran means-ends analysis terhadap kemampuan berpikir kritis matematika siswa kelas VIII SMP N 1 Rao tahun pelajaran 2018/2019. JURING (Journal for Research in Mathematics Learning), 2(2), 111. https://doi.org/10.24014/juring.v2i2.7344

Astuti, P., Purwoko, P., \& Indaryanti, I. (2017). Pengembangan LKS untuk melatih kemampuan berpikir kritis dalam mata pelajaran matematika di kelas VII SMP. Jurnal Gantang, 2(2), 145-155. https://doi.org/10.31629/jg.v2i2.244
Atika, N., \& MZ, Z. A. (2016). Pengembangan LKS berbasis pendekatan RME untuk menumbuhkembangkan kemampuan berpikir kritis matematis siswa. Suska Journal of Mathematics Education, 2(2), 103. https://doi.org/10.24014/sjme.v2i2.2126

Ennis, R. H. (1996). Critical thinking dispositions: their nature and assessability. Informal Logic, 18(2), 165-182. https://doi.org/10.22329/il.v18i2.2378

Fauzi, A. M., \& Abidin, Z. (2019). Analisis keterampilan berpikir kritis tipe kepribadian thinking-feeling dalam menyelesaikan soal PISA. Suska Journal of Mathematics Education, 5(1), 1. https://doi.org/10.24014/sjme.v5i1.6769

Hanafi, A. N. (2019). Efektivitas model pembelajaran creative problem solving terhadap disposisi matematis dan kemampuan berpikir kritis siswa pada materi trigonometri kelas X MA Mathalibul Huda Mlonggo Jepara tahun ajaran 2018/2019. Universitas Islam Negeri Walisongo Semarang.

Hendriana, H., Rohaeti, E., \& Sumarmo, U. (2017). Hard skills dan soft skills matematik siswa. Reflika Aditama.

Husnawati, N., Sanapiah, S., \& Abidin, Z. (2015). Pengaruh model pembelajaran creative problem solving terhadap kemampuan berpikir kritis matematika siswa kelas VII SMP Negeri 2 Kopang. Media Pendidikan Matematika, 3(1), 1-7.

Imamuddin, M., Fitri, H., \& Rahmadila, R. (2019). Hubungan game online dengan kemampuan berpikir kritis matematis siswa kelas VIII SMP. Jurnal Tadris Matematika, 2(1), 11-20. https://doi.org/10.21274/jtm.2019.2.1.1122

Isrok'atun, \& Rosmala, A. (2018). Model-model pembelajaran matematika. Bumi Aksara.

Istarani, \& Ridwan, M. (2014). 50 Tipe pembelajaran kooperatif. Media Persada.

Jumaisyaroh, T., Napitupulu, E. E., \& Hasratuddin, H. (2015). Peningkatan kemampuan berpikir kritis matematis dan kemandirian belajar siswa smp melalui pembelajaran berbasis masalah. Kreano, Jurnal Matematika Kreatif-Inovatif, 5(2), 157.

https://doi.org/10.15294/kreano.v5i2.3325 
Lestari, W. (2017). Pengaruh kemampuan awal matematika dan motivasi belajar terhadap hasil belajar matematika. Jurnal Analisa, $3(1)$, 76. https://doi.org/10.15575/ja.v3i1.1499

Mardaleni, D., Noviarni, N., \& Nurdin, E. (2018). Efek strategi pembelajaran scaffolding terhadap kemampuan pemecahan masalah matematis berdasarkan kemampuan awal matematis siswa. JURING (Journal for Research in Mathematics Learning), 1(3), 236. https://doi.org/10.24014/juring.v1i3.5668

Mawarni, J., Syahbana, A., \& Septiati, E. (2019). Pengaruh strategi pembelajaran REACT terhadap kemampuan berpikir kritis ditinjau dari kemampuan awal siswa SMP. Jurnal Inovasi Pendidikan Matematka, 1(2), 1-9.

Misrayanti, M., \& Amir, Z. (2019). Pengaruh penerapan model pembelajaran group investigation terhadap pemahaman konsep matematis ditinjau dari kemampuan awal matematis siswa MTs. JURING (Journal for Research in Mathematics Learning), 1(3), 207. https://doi.org/10.24014/juring.v1i3.4761

Muhibbin. (2008). Psikologi belajar. Raja Grafindo Persada.

Nindiasari, H., Kusumah, Y. S., Sumarmo, U., \& Sabandar, J. (2014). Pendekatan metakognitif untuk meningkatkan kemampuan berpikir reflektif matematis siswa SMA. Edusentris, 1(1), 80. https://doi.org/10.17509/edusentris.v1i1.13 6

Novitasari, D. (2015). Penerapan pendekatan pembelajaran creative problem solving (CPS) sebagai upaya meningkatkan kemampuan berpikir kritis matematis siswa. Jurnal Pendidikan Matematika \& Matematika, $\quad$ 1(1), 43-56. https://jurnal.umj.ac.id/index.php/fbc/articl e/view/1627/1380

Nurjannah, Z., \& Irma, A. (2019). Pengaruh penerapan model pembeljaran creative problem solving terhadap kemampuan berpikir kreatif matematis ditinjau dari kemandirian belajar siswa SMP Negeri 40 Pekanbaru. JURING (Journal for Research in Mathematics Learning), 1(3), 227. https://doi.org/10.24014/juring.v1i3.4776

Permendikbud. (2016). Peraturan Menteri Pendidikan dan Kebudayaan Republik
Indonesia Nomor 20 Tahun 2016 tentang Standar Kompetensi Lulusan (SKL) Pendidikan Dasar dan Menengah.

Praptiwi, P., \& Handhika, J. (2012). Efektivitas metode kooperatif tipe Gi dan Stad ditinjau dari kemampuan awal. Jurnal Penelitian Pembelajaran Fisika, 3(1/april), 41-50. https://doi.org/10.26877/jp2f.v3i1/april.384

Retnawati, H., Djidu, H., Kartianom, Apino, E., \& Anazifa, R. D. (2018). Teachers' knowledge about higher-order thinking skills and its learning strategy. Problems of Education in the 21st Century, 76(2), 215230.

Siregar, N. A. R., Deniyanti, P., \& Hakim, L. El. (2018). Pengaruh model pembelajaran core terhadap kemampuan berpikir kritis dan disposisi matematis ditinjau dari kemampuan awal matematika siswa SMA negeri di Jakarta Timur. Jurnal Penelitian Dan Pembelajaran Matematika, 11(1). https://doi.org/10.30870/jppm.v11i1.2997

Sunardi, Kurniati, D., Sugiarti, T., Yudianto, E., \& Nurmaharani, R. (2017). Pengembangan indikator 4C's yang selaras dengan Kurikulum 2013 pada mata pelajaran matematika SMA/MA Kelas X Semester 1. Admathedu: Jurnal Ilmiah Pendidikan Matematika, Ilmu Matematika Dan Matematika Terapan, 7(2), 197-210.

Suprapto, E. (2017). Pengaruh model pembelajaran kontekstual, pembelajaran langsung dan motivasi berprestasi terhadap hasil belajar kognitif. Innovation of Vocational Technology Education, 11(1), 23-40.

https://doi.org/10.17509/invotec.v11i1.483 6

Suryosubroto, B. (2009). Prose belajar mengajar di sekolah. Rineka Cipta.

Wahyuni, R., Mariyam, M., \& Sartika, D. (2018). Efektivitas model pembelajaran creative problem solving (CPS) dalam meningkatkan kemampuan berfikir kritis matematis siswa pada materi persamaan garis lurus. JPMI (Jurnal Pendidikan Matematika Indonesia), 3(1), 26. https://doi.org/10.26737/jpmi.v3i1.520

Zetriuslita, Ariawan, R., \& Nufus, H. (2016). Students' critical thinking ability: Description based on academic level and gender. Journal of Education and Practice, $7(12)$, 
https://files.eric.ed.gov/fulltext/EJ1099476.

pdf

Zulkarnain, I. (2019). Pengaruh kemampuan awal terhadap prestasi belajar matematika siswa. Jurnal Ilmu Pendidikan (JIP) STKIP Kusuma Negara, 11(2), 88-94. https://doi.org/10.37640/jip.v11i2.94 